\title{
Effect of different stocking densities on growth and survival of Seabass Fish (Lates calcarifer) nursery phase in low salinity
}

Mochammad Noval ${ }^{1, a}$, Hany Handajani ${ }^{1, b, *}$, Hariyadi $^{1, c}{ }^{1, c}$

${ }^{1}$ Aquaculture Department, Faculty of Agriculture and Animal Science, University of Muhammadiyah Malang, Indonesia.

amochammad.noval19@gmail.com bhandajani@umm.ac.id chariyadi@umm.ac.id ${ }^{*}$ Corresponding author

ARTICLE INFO

\section{Keywords:}

Lates calcarifer

Recirculation system

Seabass

Stress stocking

\section{ABSTRACT}

Increased production of Seabass fish (Lates calcarifer) influences the stocking density used. The purpose of this study was to determine the growth and survival of Seabass (Lates calcarifer) at different densities of low salinity stocking. The study was conducted in May-June 2019 at the Laboratory of Fisheries, University of Muhammadiyah Malang. The material used in the study of Seabass fish (Lates calcarifer) as many as 550 fish with a size of $7 \mathrm{~cm}$ and fish feed in the form of B2 Stella. The method used was experimental with a completely randomized design (CRD) with 4 treatments and 3 replications, namely $1 \mathrm{fish} / 2 \mathrm{~L}$ as control (A); 2 fish/2 L (B); 3 fish/2 L (C); 4 fish/2 L (D). Data analysis used anova $(P<0.05)$ and tested further with the Least Significant Difference Test of $5 \%$. The results showed that treatment B $(51 \pm 2$ fish/ $2 \mathrm{~L})$ produced a specific growth rate of length and weight, survival rate, efficiency of feed utilization, and feed conversion ratio which was better than treatment $A(67 \pm 1$ fish/ $2 \mathrm{~L}$ (control)), C (44 \pm 3 fish/2 L and D (38 \pm 4 fish/2 L).

How to cite:

Noval M, Handajani H, Hariyadi. 2019. Effect of different stocking densities on growth and survival of Seabass Fish (Lates calcarifer) nursery phase in low salinity. IJOTA, 2(2): 73-79.

DOI: https://doi.org/10.22219/ijota.v2i2.9595

Copyright (c) 2019, Noval et al. This is an open access article under the CC-BY-SA license

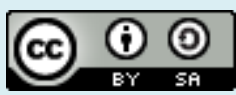

\section{Introduction}

Seabass Fish (Lates calcarifer Bloch, 1790) is a fish that has high economic value and high nutritional value as a consumption fish. Based on protein and fat content, including type $A$ fish with high protein category (15-20\%) and low fat content (5\%); and $80.3 \%$ water; $0 \%$ carbohydrate; and ash $1.1 \%$ (Afrianto and Liviawaty, 2005). The development of Seabass cultivation has been done a lot and has also become a commercial business to be developed because its growth is 
relatively fast, easily maintained and has a high tolerance for environmental changes and habitat and distribution of very large Seabass ranging from sea water, water brackish, until fresh water.

Seabass fish is very tolerant of low-salinity environments because most of its life span is two to three years in fresh waters such as lakes and rivers (Rayes et al., 2013). The application of the Seabass fish cultivation method varies from pond cultivation, floating net cages, and ponds that require large tracts of land. For small scale cultivation, you can use fiber tubs, round ponds, and aquarium containers with a recirculation system. So in this study a study of different stocking densities on the survival and growth of Seabass fish at a low salinity recirculation system.

\section{Material and methods}

The materials used in the study include the Seabass Fish (Lates calcarifer) size of $7 \mathrm{~cm}$ as many as 550 fish obtained in a group of fish farmers in Situbondo Regency, fish feed in the form of B2, and seawater with 0 to $5 \mathrm{~g} \mathrm{~L}^{-1}$ salinity. This research is an experimental study conducted at the Laboratory of Fisheries, University of Muhammadiyah Malang in April to May 2019. The equipment used in this research is aquariums of $60 \times 30 \times 30 \mathrm{~cm}$, filters, aeration stones. The experimental design used in this study was a completely randomized design (CRD). The study used 4 treatments with 3 replications.

$$
\begin{aligned}
& \mathrm{P} 1=1 \mathrm{fish} / 2 \mathrm{~L}(18 \mathrm{fish} / 36 \mathrm{~L}) \\
& \mathrm{P} 2=2 \mathrm{fish} / 2 \mathrm{~L}(36 \mathrm{fish} / 36 \mathrm{~L}) \\
& \mathrm{P} 3=3 \text { fish } / 2 \mathrm{~L}(54 \mathrm{fish} / 36 \mathrm{~L}) \\
& \mathrm{P} 4=4 \text { fish } / 2 \mathrm{~L}(72 \mathrm{fish} / 36 \mathrm{~L})
\end{aligned}
$$

The data obtained were then analyzed by variance (ANOVA) to determine the effect of the treatment given on plant growth, water quality and survival and growth of fish. If there are differences will be further tested (BNT) to see the best treatment.

\section{Results and Discussion}

\subsection{Specific growth rate (SGR).}

Specific Growth Rate is a measurement of the percentage growth in growth per day. Growth is related to the problem of changes in magnitude as measured by weight and length. Growth measurement aims to determine the addition of weight growth and length of Seabass fish (Lates calcarifer) with different stocking densities. Specific growth in the study using measurements of the addition of the growth rate for specific weights and the growth rate for specific lengths for 14 days. Specific weight growth data can be seen in the following Figure 1. The data obtained for the growth rate of the Seabass specific weight, the highest data value is the P2 treatment at $0.90 \%, \mathrm{P} 1$ treatment at $0.67 \%, \mathrm{P} 3$ treatment at $0.58 \%$, and P4 treatment at $0.56 \%$. At a specific weight growth rate decreased in the treatment of P3 and P4, this is thought to be more densely stocking density, it can cause the growth rate of specific weight decreases in Seabass.

Based on Figure 2, the data obtained the growth rate of the specific length of the Seabass fish, the highest data value is the P2 treatment at $0.78 \%, \mathrm{P} 1$ treatment at $0.46 \%, \mathrm{P} 4$ treatment at $0.42 \%$, and $\mathrm{P} 3$ treatment at $0.38 \%$. At the specific length growth rate decreased in the treatment of P3 and P4, this is assumed to be the same as the growth rate of specific weight that the more 
stocking density, it can cause the growth rate of specific length decreases in the Seabass. During the 14 days maintenance of Seabass fish there was an increase in weight in each treatment, P1 treatment was $0.67 \%$, P2 treatment was $0.90 \%$, P3 treatment was $0.58 \%$, and P4 treatment was $0.56 \%$. The results of the growth rate of the specific weight of the most prominent in the P2 treatment was $0.90 \%$, while the growth rate for the specific length experienced a length increase in each treatment, P1 treatment was $0.46 \%$, P2 treatment was $0.78 \%$, P3 treatment amounted to 0.38 , and treatment P4 of 0.42 .

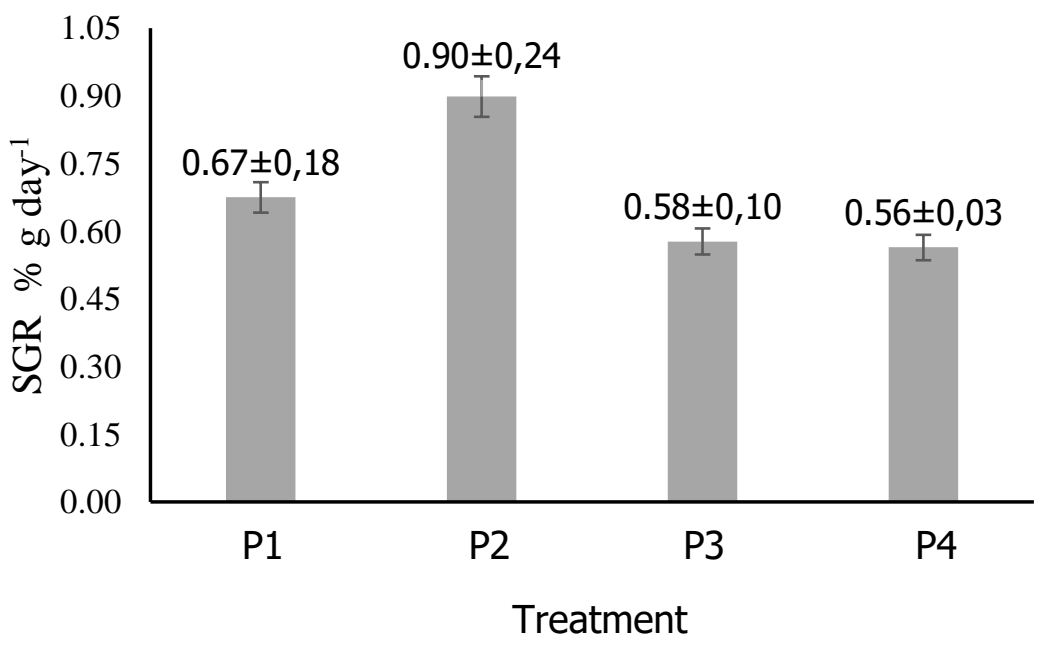

Figure 1. Specific growth rate of weight.

The results of the growth data of the specific length of the Seabass fish were most prominent in the P2 treatment were $0.78 \%$. Growth data of specific weights and lengths of the Seabass fish that have a very significant effect on P2 treatment are due to low stocking density even though the P1 treatment is also low in thickness but the results of research from both P1 and P2 treatments have the greatest value of the P3 treatment and P4, where the P3 and P4 treatments are very high.

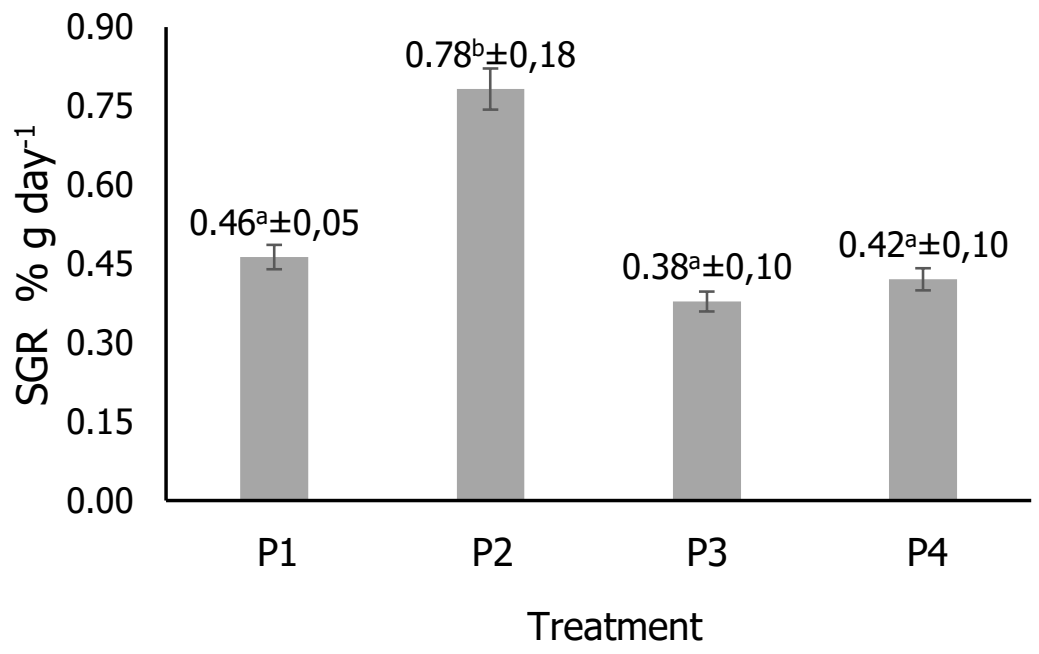

Figure 2. Specific growth rate of Length.

In the opinion of Rayes et al., (2013) fish growth can occur if the energy stored is greater than the energy used for bodily activities. Then competition that occurs such as space and ability to get food take place well without causing fish stress and stunted growth during maintenance (Santoso, 2015). Generally fish need energy derived from feed to grow while a low amount of feed 
will inhibit growth, but several studies have shown that fish fed with low amounts of food will grow faster when feeding begins again (Rosniar, 2013). In addition, growth can be influenced by low and high stocking densities where the higher the stocking density of Seabass fish, the lower the growth rate of specific weights and lengths on the results of the study. This is supported by the statement of Tarwiyah (2001) that if the stocking density is higher, the daily growth rate of fish is low so that it can be expected that the treatment of high stocking densities inhibits the growth of Seabass fish compared to low stocking density treatment.

\subsection{Feed convertion ratio (FCR).}

Feed conversion ratio is the ratio between body weight of fish for feeding fish, the smaller the value of feed conversion, the smaller the feed requirements used for fish. Data from observations of feed conversion ratio with different stocking densities can be seen in Figure 3.

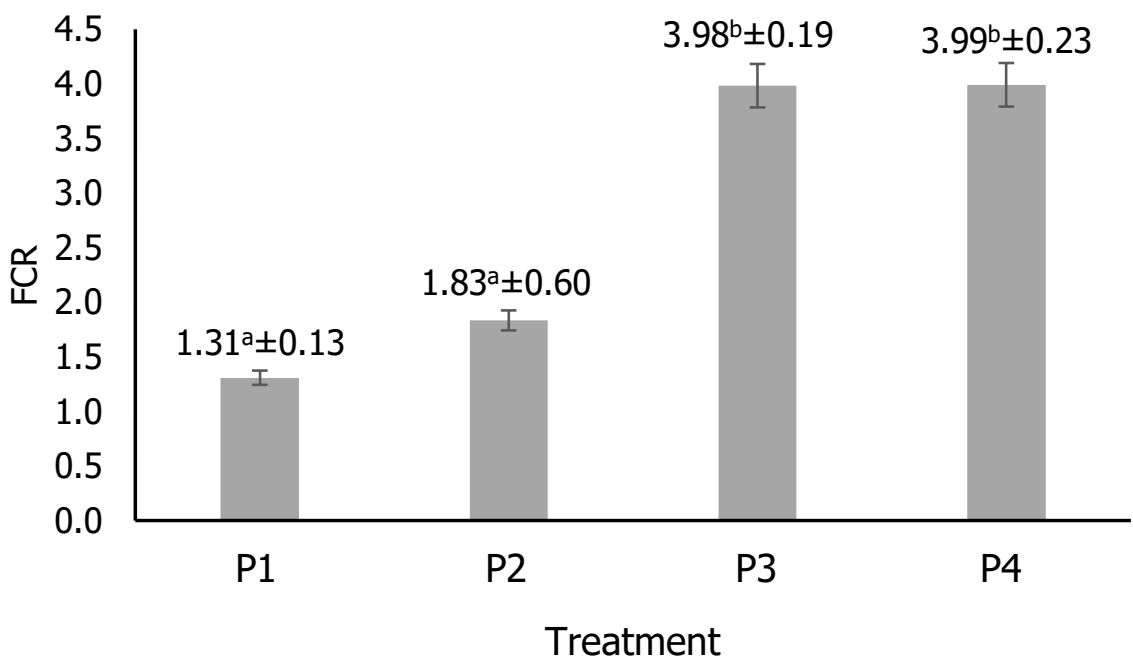

Figure 3. Feed convertion ratio of Seabass.

Based on Figure 3, data obtained in the form of observations of the conversion ratio of Seabass fish feed, in this observation the highest value in P1 treatment was 1.31, P2 treatment was 1.83, P3 treatment was 3.98, and P4 treatment was 3.99. In this study the conversion ratio of Seabass fish feed increased from P1 to P4 treatments where the best feed conversion value was the smallest because the smaller the value of the feed conversion ratio, the better. The value of the small feed conversion ratio is due to the smaller stocking due to the small stocking density of fish able to get good feed. According Tahapari and Suhenda (2009) that the value of a 1.5-2.0 feed conversion range is considered the best for the growth of most species of fish. The lower the value of the feed conversion ratio, the better the use of feed. Fish adapted to fresh water to produce $1 \mathrm{~kg}$ of fish need $0.9 \mathrm{~kg}$ of feed, whereas seawater, brackish water and high salinity sea water to produce $1 \mathrm{~kg}$ of fish need $2 \mathrm{~kg}$ of feed.

\subsection{Efficiency of feed utilization (EFU).}

Efficiency of feed utilization is the amount of feed weight consumed by looking at the weight of fish biomass that is kept or showing how much fish utilizes feed on its body, whether or not a quality of feed is not only seen from the value of the feed conversion ratio but can be seen from the value of the efficiency of feed utilization because it is increasingly the greater the value of the 
efficient use of feed in fish, the more efficient the fish use the feed consumed for its growth. Data on the results of observations of the efficiency of feed utilization with different stocking densities can be seen in Figure 4.

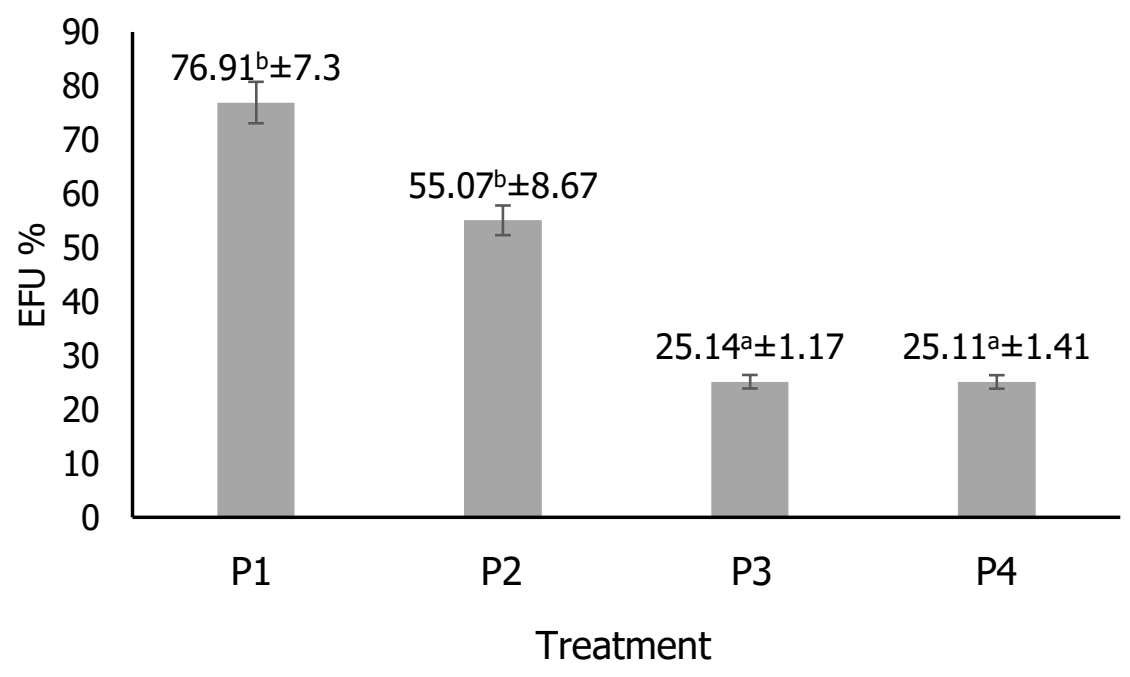

Figure 4. Efficiency of feed utilization

Based on Figure 4 obtained data in the form of observations on the efficiency of utilization of Seabass fish feed, in this observation the highest value in the P1 treatment was $76.91 \%, \mathrm{P} 2$ treatment was $55.07 \%$, P3 treatment was $25.14 \%$, and treatment was P4 $25.11 \%$. In research on the utilization efficiency of Seabass fish feed, it has increased from treatment P1 to P4 treatment where the best value of feed utilization efficiency has the greatest value because the greater the efficiency of feed utilization, the better the fish will use feed for its growth. This is supported by the statement of Sunarto and Sabariah (2012) that the low value of feed consumption shows that the level of efficiency is higher in utilizing food for growth, while the high value of feed consumption indicates that the level of efficiency is lower in utilizing food for growth. According to Puspasari et al., (2015) that the value of good feed utilization efficiency is more than $50 \%$ or even close to $100 \%$.

\subsection{Survival rate $(S R)$.}

Survival is the level of passing of an organism's life from a population within a certain period or the survival of organisms from the environment within a specified time (Agustin et al., 2014). Data from observations of survival research can be seen in Figure 5. The data obtained in the form of observations of the survival of the Seabass fish, in this observation the highest value in the treatment P1 of $67 \%$, treatment P2 of $51 \%$, treatment of P3 by $44 \%$, and treatment of P4 by $38 \%$. In the study the survival rate of Seabass fish decreased in P2 treatment, P3 treatment, and P4 treatment. The death of the fish is due to the higher stocking density so that the Seabass has limited dissolved oxygen which makes the fish easily stressed.

According to Utami et al., (2018) high density causes oxygen competition and maintains its graduation due to unstable oxygen supply, as seed growth increases, body size becomes larger, body contact often occurs with increased oxygen and feed requirements, but space is increasingly narrow, resulting in impact on stress and very high fish mortality. The higher the stocking density 
of the Seabass fish the impact of stress on the fish, because stress can cause the fish's body to decrease which will eventually cause death.

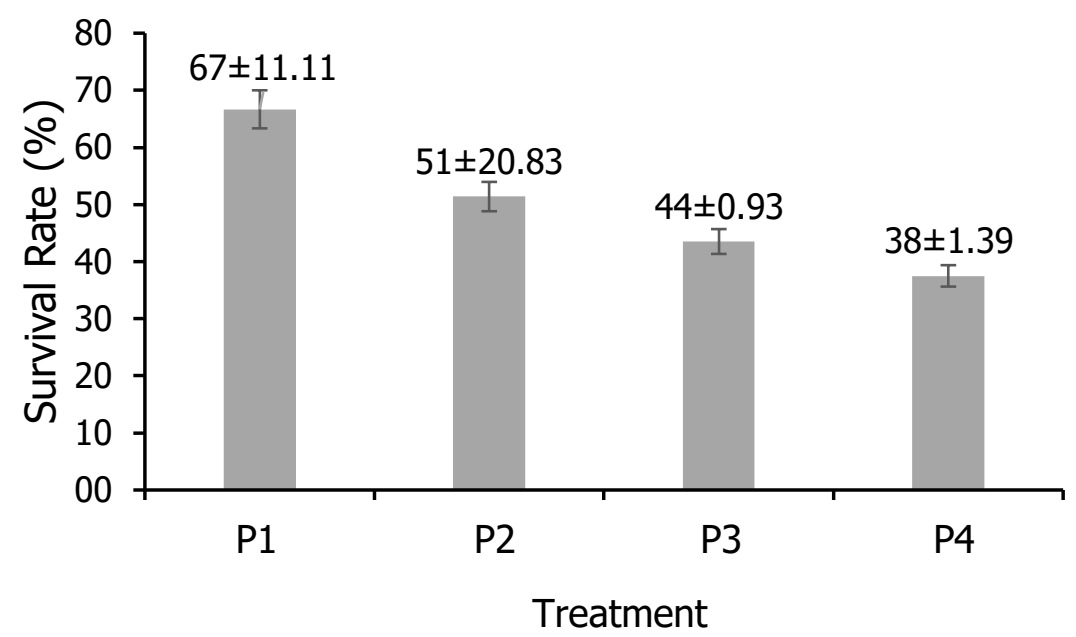

Figure 5. Survival rate of Seabass.

\subsection{Water quality.}

Water quality is a very important media during the research to support the success of the Seabass cultivation. In this study, water quality is maintained even though the research uses a recirculation system by utilizing bio filter in the form of dacron which acts as a physical biofilter and the use of pumice which acts as a biofilter biologically, in addition to maintaining water quality in order to remain good in research siphon off any leftovers that are not eaten so that the leftovers do not become ammonia for fish. The water quality of the Seabass seeds observed during the study included: Temperature $\left({ }^{\circ} \mathrm{C}\right)$, Degree of acidity $(\mathrm{pH})$, Dissolved oxygen $\left(\mathrm{mg} \mathrm{L}^{-1}\right)$, and salinity $\left(\mathrm{g} \mathrm{L}^{-1}\right)$. The results of water quality in this study can be seen in Table 1.

Table 1. Water Quality Parameters.

\begin{tabular}{|c|c|c|c|c|c|c|}
\hline \multirow[b]{2}{*}{ Parameter } & \multirow[b]{2}{*}{ Unit } & \multicolumn{4}{|c|}{ Treatment } & \multirow[b]{2}{*}{$\begin{array}{l}\text { Optimum } \\
\text { range }\end{array}$} \\
\hline & & $\begin{array}{c}\mathrm{P} 1 \\
(1 \mathrm{fish} / 2 \mathrm{~L})\end{array}$ & $\begin{array}{c}\text { P2 } \\
\text { (2 fish/2 L) }\end{array}$ & $\begin{array}{c}\mathrm{P3} \\
(3 \mathrm{fish} / 2 \mathrm{~L})\end{array}$ & $\begin{array}{c}\text { P4 } \\
\text { (4 fish/2 L) }\end{array}$ & \\
\hline Temperature & ${ }^{\circ} \mathrm{C}$ & $23-28$ & $23-28$ & $24-29$ & $23-29$ & $26-32^{*}$ \\
\hline DO & $\mathrm{mg} \mathrm{L}^{-1}$ & $5.0-6.8$ & $3.8-7.5$ & $5.2-7.5$ & $3.2-7.8$ & $4^{*}$ \\
\hline $\mathrm{pH}$ & ppm & $7.0-8.4$ & $7.0-8.4$ & $7.0-8.2$ & $7.0-8.5$ & $7.0-8.5^{* *}$ \\
\hline Salinity & $\mathrm{ppt}$ & $0-6$ & $0-6$ & $0-6$ & $0-6$ & $0-40^{* *}$ \\
\hline
\end{tabular}

The data in Table 1 shows the temperature at the time of the study ranged from 23 to $29^{\circ} \mathrm{C}$ using a thermometer placed in the aquarium. This shows according to the opinion in Rayes et al., (2013) the optimal temperature for the life and growth of the Seabass fish is 25 to $30{ }^{\circ} \mathrm{C}$. PH measurements show values ranging from 7.0 to 8.5 using a $\mathrm{pH}$ meter. This is consistent with the opinion of Rayes et al., (2013) that the optimum pH range is 7.5 to 8.5. DO measurements show values ranging from 3.2 to $7.5 \mathrm{mg} \mathrm{L}^{-1}$ using a DO meter. This is consistent with the statement of Rayes et al., (2013) that dissolved oxygen of adult Seabass requires dissolved oxygen 6.5 to 12.5 $\mathrm{mg} \mathrm{L}^{-1}$. Salinity measurements show values ranging from 0 to $6 \mathrm{~g} \mathrm{~L}^{-1}$ using a refractometer. This is consistent with Agustin's research (2018) that Seabass fish have a high tolerance to salinity that is 
0 to $40 \mathrm{~g} \mathrm{~L}^{-1}$. The optimum range of salinity value in Seabass fish for life and growth is 15 to 28 (SNI, 2000).

\section{Conclusion.}

Effect of Different Stocking Density of Seabass fish (Lates calcarifer) Seedling growth phase at low salinity obtained results that were not significantly different from parameters including weight growth, survival, while on long growth, feed conversion ratio, and efficiency of feed. White is significantly different. A good stocking density in this study was P2 treatment (2 fish / $2 \mathrm{~L}$ ) where the results of growth in weight, length, feed conversion ratio, and efficiency of feed utilization were better, whereas P1 treatment (1 fish / $2 \mathrm{~L}$ ) results in better life graduation so that the solid optimum stocking in Seabass fish cultivation with a recirculation system is 1 to 2 fish / $2 \mathrm{~L}$.

\section{References}

Afrianto E, Liviawaty E. 2005. Pakan Ikan. Fifth Edition. Kanisius. Yogyakarta.

Agustin R, Sasanti AD, Yulisman. 2014. Konversi pakan, laju pertumbuhan, kelangsungan hidup dan populasi bakteri benih ikan Gabus (Channa striata) yang diberi pakan dengan penambahan probiotik. Jurnal Akuakultur Rawa Indonesia. 2(1): 55-66.

Agustine MUT. 2018. Keragaan benih ikan Kakap Putih (Lates calcarifer)yang dipelihara pada waring apung di tambak dengan padat tebar berbeda pada fase pendederan. SKRIPSI. Universitas Lampung.

Puspasari T, Andriani Y, Hamdani H. 2015. Pemanfaatan bungkil kacang tanah dalam pakan ikan terhadap laju pertumbuhan ikan Nila (Oreochromis niloticusi). Jurnal Perikanan Kelautan. 6(2): 91-100.

Rayes RD, Sutresna IW, Diniarti N, Supii AI. 2013. Pengaruh perubahan salinitas terhadap pertumbuhan dan sintasan ikan kakap putih (Lates calcarifer). Jurnal Kelautan. Vol. 6(1): 47-56.

Rosniar F. 2013. Peningkatan nafsu makan dan pertumbuhan pada pendederan ikan Kerapu Macan (Epinephelus fuscoguttatus) melalui periode pemuasaan berbeda. Institut Pertanian Bogor. Jurnal Manajemen Akuatik. 2(3): 9-16.

Santoso B. 2015. Teknik Pembesaran Ikan Kakap Putih (Lates calcarifer) di tambak secara semiintensif di Balai Layanan Usaha Produksi Perikanan Budidaya (BLUPPB). Perpustakaan Universitas Airlangga Karawang. Jawa Barat.

SNI (Standar Nasional Indonesia). 2000. Produksi Pembesaran Ikan Kakap putih (Lates calcalifer) Kelas Pembesaran. Badan Standarisasi Nasional. SNI 01- 64931 -2000.

Sunarto dan Sabariah. 2012. Pemberian pakan buatan dengan dosis berbeda terhadap pertumbuhan dan konsumsi pakan benih ikan Semah (Tor douronensis) dalam upaya domestikasi. Jurnal Akuakultur Indonesia. 8(1): 67-76.

Tahapari E, Suhenda N. 2009. Penentuan frekuensi pemberian pakan untuk mendukung pertumbuhan benih ikan Patin Pasupati. Berita Biologi. 9(6): 693-698.

Tarwiyah. 2001. Pembesaran Ikan Kakap Putih (Lates calcalifer) di keramba jaring apung. Direktorat Jenderal Perikanan, Departemen Pertanian. Jakarta. $5 \mathrm{hlm}$.

Utami KP, Hastuti S, Nugroho RA. 2018. Pengaruh kepadatan yang berbeda terhadap efesiensi pemanfaatan pakan, pertumbuhan dan kelulusanhidupan ikan Tawes (Puntius javanicus) pada sistem resirkulasi. Jurnal Sains Akuakultur Tropis: 2(2): 53-63. 